\title{
Zea mays Antigen IgE Antibody Measurement
}

National Cancer Institute

\section{Source}

National Cancer Institute. Zea mays Antigen IgE Antibody Measurement. NCI Thesaurus. Code C147279.

The determination of the amount of Zea mays antigen IgE antibody present in a sample. 